\title{
BEHAVIOR OF GLASS FIBER GEOPLOYMER BUBBLE SLABS EXPOSED TO FIRE FLAME
}

\author{
${ }^{*}$ Hussain K. Jawad ${ }^{1}$
}

Waleed A. Waryosh ${ }^{1}$

1) Civil Engineering Department, College of Engineering, Mustansiriyah University, Baghdad, Iraq

\begin{abstract}
In the present study, eight specimens of Reinforced concrete Geopolymer bubbled slab exposed to fire flame and tested under punching shear failure with dimensions $(45 * 45 * 7 \mathrm{~cm})$, steel armature ( plastic ball diameter $(4 \mathrm{~mm})$ and concrete cover $(1.5 \mathrm{~cm})$ and the use of two percentages of fiberglass $(0.5 \%-1 \%)$ and the variable temperatures were $\left(150-300-450{ }^{\circ} \mathrm{C}\right)$ with a burning time of 30 minutes. From the results of laboratory tests, when the Geopolymer reinforced concrete bubbled slabs exposed to high temperatures, it did not occur to spalling, and the reason for that is that Geopolymer concrete has the ability to resist heat due to the fact that it's main compounds are materials burned at high temperatures. And also, it was noticed in examining a punching shear stress of the models with fibers $(0.5 \%)$ that the ultimate load increased by $(4.5 \%)$ for the model burned at a temperature of $\left(150^{\circ} \mathrm{C}\right)$ and a decrease in the ultimate load was $(40 \%)$ for the models burned at temperatures $\left(300{ }^{\circ} \mathrm{C}\right)$ and a decrease in the ultimate load by (30\%) for the models burned at temperatures $\left(450^{\circ} \mathrm{C}\right)$. Also, it was noticed in examining a punching shear stress of the models with fibers (1\%) that the ultimate load increased by (6\%) for the model burned at a temperature of $\left(150{ }^{\circ} \mathrm{C}\right)$ and a decrease in the ultimate load was $(36 \%)$ for the models with temperatures $\left(300{ }^{\circ} \mathrm{C}\right)$ and a decrease in the ultimate load by $(27 \%)$ for the models burned at temperatures $\left(450^{\circ} \mathrm{C}\right)$.
\end{abstract}

Keywords: Geopolymer, punching shear, glass fiber, bubbled, Fire flam.

\section{Introduction}

Reinforced concrete (RC) structures are subjected to different types of load such as gravity load, wind load, earthquake and fire.
When RC structures are subjected to high temperatures, loss in capacity will take place. Slab is important structural element that may be exposed to fire. In recent years; new system of voided slabs used in many projects known as bubble slab; bubble slab consists of plastic balls place at middle depth of conventional slab and these balls Have small influence on structural performance [1]. Normal weights concrete in recent years in some projects replaced by Geopolymer concrete due to the great mechanical properties of the new concrete. Because this type of concrete has technical advantages over traditional concrete such as, greater resistance to compression, low heat of hydration, high chemical resistance, and exceptional resistance to the sulfate attacks. Geo-polymer concrete may be considered as sustainable concrete [2]. Replacing cement by Aluminosilicate source materials like ground granulated blast furnace slag, metakaolin, fly ash, and rice husk ash eliminate the $\mathrm{CO} 2$ emissions and energy consumption of cement industry [3]. Producing geopolymer concrete is not a complicated process, it follows the same procedure of producing cement concrete but with one added step. The source material needs to be activated with highly alkaline solutions

\footnotetext{
*Corresponding Author: albayaa95@ gmail.com
} 
just like Sodium or Potassium Silicate and Sodium or Potassium Hydroxide. [4, 5]

In 2012, Fifteen reinforced concrete square slabs of $(1000 \times 1000 \mathrm{~mm})$ with plastic voids were investigated both experimentally and analytically by Salman [6]. The thickness of the specimens is $(80,100$ and $125 \mathrm{~mm})$ depending on the diameter of plastic spheres $(64,80$ and $100 \mathrm{~mm})$. The main parameters that were studied are the thickness of the slabs, tension steel reinforcement area (310, 485 and 698 $\mathrm{mm} 2 / \mathrm{m}$ ), type of construction method (simple type and filigree (semi-precast) type) and percentage of Metakaolin (cement replacement $5 \%, 10 \%$ and $20 \%$ ). Test results showed that, the bubbled slab has about (90-100\%) of ultimate load capacity related to the reference solid slab (which has same slab thickness). Furthermore, increase in deflection at $0.7 \mathrm{Pu}$ by approximately (17-27\%) has been indicated.

In 2015 Al-Attar etal. [7], have proposed the optimization of the mix design of the polymer concrete through adopting 10 Molar of the alkaline. Various ratios of (sodium hydroxide/ sodium silicate) like $(3.50 \& 1)$ have been chosen, 12 cubes with $(150 \mathrm{~mm} \times 150 \mathrm{~mm} \times$ $150 \mathrm{~mm})$ dimensions have been tested. The results of the test have shown that optimal superplasticizer dosage has been $(12 \mathrm{~kg} / \mathrm{m} 3)$ increasing concrete's compressive strength. In 2020 Wissam Kadhim et al. [8] Tested fifteen $700 \mathrm{~mm} \times 500 \mathrm{~mm}$ concrete flat slabs that have been made of Geo-polymer concrete have been tested under concentrated for identifying maximal punching shear resistance under an impact of a variety of the parameters like the slab thickness, steel fiber content, ratio of flexural reinforcement, besides the replacement of $10 \%$ of the metakaolin by silica fume under impact of the temperature that increases up to $300^{\circ} \mathrm{C}$ besides testing 90 control samples for investigating mechanical characteristics. It has been noticed that there was a start to change in structural behaviors in the case where temperature had reached $100 \mathrm{C}^{\circ}$ as a result of an increase in pressure by liquid vapor, then a significant decrease in the behavior and capacity when reaching a temperature of $300^{\circ} \mathrm{C}$. The existence of the iron fibers results in the decrease of distance between the column edge and critical section that had decreased the values of the punching shear. The decrease in the maximum and cracking of punching shear have been recorded respectively at $37 \%$ and $42 \%$, in the case where temperature had been increased to $300^{\circ} \mathrm{C}$. The material properties that adopted in study. From experimental results it is concluded that

In 2019 Haitham H. [1] studied the behavior of reinforced concrete bubbled slabs exposed to fire flame. The experimental work involved casting and burning nine specimens under static load. The dimension of specimens was (700x450x80) $\mathrm{mm}$, all specimens have same compressive strength $30 \mathrm{MPa}$ (normal concrete), ball diameter was $40 \mathrm{~mm}$, ratio of reinforcement at top and bottom of slabs 0.00417 , fire flame temperature was $(200,300$ and 400$){ }^{\circ} \mathrm{C}$, fire flame duration (30 and 60) minutes and concrete cover $(20$ and 10) $\mathrm{mm}$. The specimens were simply supported in two directions. The test results showed that, $\mathrm{RC}$ bubble slab exposed to $200^{\circ} \mathrm{C}$ at 30 and 60 minutes with $20 \mathrm{~mm}$ cover spalling not happened but in specimen with 10 $\mathrm{mm}$ concrete cover spalling occurred. All RC bubble slab exposed to $300^{\circ} \mathrm{C}$ and $400^{\circ} \mathrm{C}$ spalling occurred, damage of spalling for bubble slabs exposed to $300^{\circ} \mathrm{C}$ in 30 -minute fire duration more than $400^{\circ} \mathrm{C}$ by $(32 \%)$ otherwise at 60-minute fire duration damage of spalling in $400^{\circ} \mathrm{C}$ more than $300^{\circ} \mathrm{C}$ by $(49 \%)$. Deflection during burning was observed due to static load and elevated of temperature, deflection increased with increasing fire flame temperature 
and duration, increase of fire duration to 60 minute from 30-minute lead to increase in deflection with fire flame rate $(200,300$ and 400) ${ }^{\circ} \mathrm{C}$ by $(57,79$ and 68$) \%$ respectively in compassion with slabs exposed same fire rate at 30 minute.

\section{Experimental Program:}

The present study includes researching mechanical characteristics, fracture modulus, compressive strength, indirect tensile and elastic modulus in addition to finding concrete's density and workability, of Geo-polymer concrete that is based upon the metakaolin and utilizing ordinary aggregate and alkali solution as coarse and fine aggregate after the exposure to the fire flames of 150,300 and $450{ }^{\circ} \mathrm{C}$, after that, researching behaviors of the geo-polymeric concrete slabs under an impact of the degree of temperature, in which the load deflection curve, maximum load, crack load, critical area, failure angle, failure type and crack pattern. The most parameters will be adopted, which are the temperature degree of burin (150, 300 and 450) ${ }^{\circ} \mathrm{C}$ and the percentage of the Glass fiber. Table (1) show the details of tested slabs.

Table 1. Tested Slabs

\begin{tabular}{|c|c|c|c|}
\hline $\begin{array}{l}\text { Number of } \\
\text { specimens }\end{array}$ & Labeling & $\begin{array}{c}\text { Fire } \\
\text { Flame } \\
\text { Rate }^{\circ} \mathrm{C}\end{array}$ & $\begin{array}{c}\text { Ratio of } \\
\text { Glass } \\
\text { Fiber \% }\end{array}$ \\
\hline 1 & GP-0.5- & Without & 0.5 \\
\hline 2 & ROOM & fire & \\
\hline 3 & GP-0.5-150 & 150 & 0.5 \\
\hline \multirow[t]{2}{*}{4} & GP-0.5-300 & 300 & 0.5 \\
\hline & GP-0.5-450 & 450 & 0.5 \\
\hline 5 & GP-1.0- & Without & 1.0 \\
\hline 6 & ROOM & fire & \\
\hline 7 & GP-1.0-150 & 150 & 1.0 \\
\hline \multirow[t]{2}{*}{8} & GP-1.0-300 & 300 & 1.0 \\
\hline & GP-1.0-450 & 450 & 1.0 \\
\hline
\end{tabular}

\section{Material and Methods:}

\subsection{Metakaolin:}

Metakaolin's nature is the clay mineral kaolinite and may be produced through the chemical compositions from $\mathrm{Al} 2 \mathrm{Si} 2 \mathrm{O} 5(\mathrm{OH}) 4$. The method and operations for the conversion of the kaolinite to the metakaolin dependent upon applied temperature, where $\left(100^{\circ}-200^{\circ} \mathrm{C}\right)$ the maximum water amount will be lost and $\left(500^{\circ}-\right.$ $700^{\circ} \mathrm{C}$ ) loss all water.

$$
\text { Al2Si2O5 }(\mathrm{OH}) 4 \rightarrow \text { Al2Si2O7 + } 2 \mathrm{H} 2 \mathrm{O}
$$

Chemical, physical and requirements that are based upon ASTM C-618 [9].

\subsection{Sodium Silicate:}

The sodium silicate $(\mathrm{Na} 2 \mathrm{SiO} 3)$ brand that has been adapted in this work have been produced in UAE show characteristics by weight that have been listed in Table2.

Table 2. Characteristics of Sodium Silicate (i.e. supplier brochure)

\begin{tabular}{cc}
\hline Descriptions & Values \\
\hline $\mathrm{SiO}_{2} / \mathrm{a}_{2} \mathrm{O}$ & $2.40 \pm .05$ \\
$\% \mathrm{H} 2 \mathrm{O}$ & 55.1 \\
$\% \mathrm{Na} 2 \mathrm{O}$ & $13.1-13.7$ \\
$\% \mathrm{SiO} 2$ & $32-33$ \\
Density & $51 \pm 0.50$ \\
Specific Gravity & $1.534-1.551$ \\
viscosity & $600-200$ \\
\hline
\end{tabular}

\subsection{Sodium Hydroxide:}

The sodium hydroxide $(\mathrm{NaOH})$ has been considered as the most significant component for preparing Geo-polymer concrete. $\mathrm{NaOH}$ that has been produced by the dissolution of the caustic flakes of soda in the water. Chemical reaction between water and $\mathrm{NaOH}$ has been an exothermic element, then, compositions cool in the air for $2 \mathrm{~h}$. test results and were compared to the requirements that are based on ASTM E29109 [10]. 
The method that that has been adapted for the preparation of the alkaline solution through preparing it from $(\mathrm{Na} 2 \mathrm{SiO} 3)$ and $\mathrm{NaOH}$ by the flaky $\mathrm{NaOH}$ of high purity $\geq(98 \%)$ in the distilled water. A $1 \mathrm{~L}$ solution has been produced through the mixing of $(560 \mathrm{~g})$ of sodium hydroxide [e.g., a 14 molar $\mathrm{NaOH}$ solution includes $14 \times 40=560 \mathrm{~g}$ of sodium hydroxide solids per a liter of the solution, 40 represents sodium hydroxide's molecular wt., O $=16, \mathrm{Na}=23, \mathrm{H}=1]$ with $(826 \mathrm{ml})$ water so that concentration by the weight is (0.404) needed to prepare 1 liter of 14 Molar $\mathrm{NaOH}$ solution, is as follows.

Concentration by weight $(\mathrm{w} / \mathrm{w})=560 /$ $(560+826)=0.404$

The Molarity (mole/l) for the mixture that has been adopted was (14) and $\mathrm{NaOH}$ flakes' weight was (404g).

Alkaline liquid preparation has been carried out through the mixing of $1 \mathrm{~L}$ from sodium hydroxide with (3.5L) from (Na2SiO3). The adopted time mixture has been (1day) prior to using the final mix.

\subsection{Crushed Gravel and Sand:}

The local sand that has been graded by zone 3 has been utilized as fine aggregate with a 2.67 fineness modulus, a $0.41 \%$ sulfate content, a $3.70 \%$ clay content, and a 2.65 specific gravity. While the crushed gravel has been utilized as coarse aggregate in which the grades have been ranging between $5 \mathrm{~mm}$ and $12 \mathrm{~mm}$ with a $0.088 \%$ sulfate content, a $2.10 \%$ clay content and a 2.61 specific gravity. All chemical and physical characteristics of the aggregates are conforming to IQ.S45/1984[11].

\subsection{Super plasticizer:}

The super plasticizer which has been utilized for preparing the geo-polymeric concrete is the Glenium 51 that has been manufactured in UAE with a light brown color, a PH 6.80, chlorinefree, and utilized at a $3 \mathrm{~L} / \mathrm{m} 3$ dosage.

\subsection{Water:}

Specimens have been casted and cured via the use of tap water.

\subsection{Reinforcement Mesh:}

Square welded meshes used to reinforcing slabs, the specifications of welded mesh were evaluated according to ASTM 185A/A185M07[12] according to manufacturer.

\subsection{Glass Fiber:}

Cem-Fil Anti-Crack, HD-12 mm, Alkali Resistant glass fibers have been utilized over experimental work. From micro to macro fiber ranges, those fibers regulate the processes of the cracking, which may happen throughout concrete's lifespan [13].

\subsection{Plastic Balls:}

In the presented study, the plastic balls have been made from recycled plastic that has a diameter of $(40 \mathrm{~mm})$.

\subsection{Mixing Geopolymer Concrete:}

The aggregates have been produced on saturated surface in dry state SSD; The aggregate (i.e. the coarse and fine aggregates) are mixed together at first in the dry forms in a bucket mixer for 3 min and after that, the Metakaolin (i.e. cement) has been added then mixed for 2 min. alkaline liquid has been added into Geo-polymer concrete mixture ( $65 \%$ of water has been added) and $65 \%$ superplasticizer has been mixed with more water for at least $2 \mathrm{~min}$. and added gradually to dry materials in mixer tray (the $65 \%$ super plasticizer was mixed with $35 \%$ of water and added to it) during five minutes. After that, the Glass fiber has been added and $35 \%$ of super plasticizer was added and mixed for two min.; after that, concrete was compacted with a vibrating table, fact the compaction requires 
much skill. [14-16]. Table (3) shown the optimum mix proportions for Geo-polymer concrete [7].

Table 3. The optimum mixture proportions for Geo-polymer concrete [7]

\begin{tabular}{ccc}
\hline Number of specimens & $1-4$ & $5-8$ \\
& & \\
\hline Metakaolin $\left(\mathrm{kg} / \mathrm{m}^{3}\right)$ & 400 & 400 \\
Sand $\left(\mathrm{kg} / \mathrm{m}^{3}\right)$ & 720 & 720 \\
Gravel $\left(\mathrm{kg} / \mathrm{m}^{3}\right)$ & 1100 & 1100 \\
Alkaline Solution $\left(\mathrm{lit} / \mathrm{m}^{3}\right)$ & 180 & 180 \\
Water $\left(\mathrm{lit} / \mathrm{m}^{3}\right)$ & 40 & 40 \\
Sp*\% & 3 & 3 \\
Glass fiber \% & 0.5 & 1 \\
\hline
\end{tabular}

Superplasticizer*

\subsection{Curing:}

Curing can be defined as placing sample under direct sun-light outside lab following the demolding for a 28 -day period. The models have been poured during temperature degrees in the range between $27^{\circ}$ and $30^{\circ}$, placed models have been under ambient temperatures, according to earlier studies.

\section{Burning Test:}

slab specimens were subjected to fire flame by burners The fire flame of Two-headed fire subjected to tension face of slab and placed on ground, the high of slab from the fire flame is $400 \mathrm{~mm}$. steel frame was used for presented the real condition of burning, the frame was closed from all sides with some openings. Thermocouple type $\mathrm{K}$ with the capacity of (-50 to 1300$){ }^{\circ} \mathrm{C}$ which was used to measure the temperature in depth of slab (at mid depth) and the infrared thermometer with ability (-32 to 550) ${ }^{\circ} \mathrm{C}$ which was used to measure the fire rate on bottom face of slab.

\section{Results and Discussion:}

\subsection{Ultimate Load:}

Ultimate load is an important value to investigate the structural behavior. Experimental results have shown that ultimate load of reinforced concrete Geopolymer bubbled slab with $(0.5 \%)$ and $(1 \%)$ Glass fiber without exposed to fire flam (GP-0.5-ROOM) (GP-1.0ROOM) was (20 and 22) $\mathrm{kN}$ respectively. When reinforced concrete Geopolymer bubbled slab with (0.5 and 1) \% Glass fiber exposed to fire flame rate $150{ }^{\circ} \mathrm{C}$ at $30 \mathrm{~min}$ ultimate load increased by (1.05 and 1.07) (GP-0.5-150) (GP1.0-150) from references slabs without exposed to fire flame. At increasing fire flame rate to 300 ${ }^{\circ} \mathrm{C}$ at same fire deration $30 \mathrm{~min}$ ultimate load decreases by (40\% to $36 \%$ ) (GP-0.5-300) (GP1.0-300) from references slabs without Exposure to fire flame. identical slabs with same Glass fiber ratio exposed to $450{ }^{\circ} \mathrm{C}$ the results show ultimate load Decreases by (30\% to 27 \%) (GP-0.5-450) (GP-1.0-450). Table (4) shows the ultimate load of tested slabs. These results of ultimate load show that in $150{ }^{\circ} \mathrm{C}$ ultimate load was improving because it strengthens the concrete expelling excess water. The strength of slabs decrease in $300{ }^{\circ} \mathrm{C}$ is more than $450{ }^{\circ} \mathrm{C}$, it is because the temperature flow rate in $450{ }^{\circ} \mathrm{C}$ faster than $300{ }^{\circ} \mathrm{C}$.

Table 4. The ultimate load tested slabs

\begin{tabular}{cccc}
\hline $\begin{array}{c}\text { Number of } \\
\text { Specimens }\end{array}$ & Labeling & $\begin{array}{c}\text { Ultimate } \\
\text { Load }(\mathrm{kN})\end{array}$ & $\begin{array}{c}\mathbf{U . ~ L} \\
\mathbf{( U . \mathbf { L } ) \mathbf { R }}\end{array}$ \\
\hline $\mathbf{1}$ & GP-0.5- & 20 & -- \\
$\mathbf{2}$ & ROOM & & \\
$\mathbf{3}$ & GP-0.5-150 & 21 & 1.05 \\
$\mathbf{4}$ & GP-0.5-300 & 12 & 0.6 \\
$\mathbf{5}$ & GP-0.5-450 & 14 & 0.7 \\
& GP-1.0- & 22 & --- \\
$\mathbf{6}$ & ROOM & & \\
$\mathbf{7}$ & GP-1.0-150 & 23.4 & 1.07 \\
$\mathbf{8}$ & GP-1.0-300 & 14 & 0.64 \\
& & 16 & 0.73 \\
\hline
\end{tabular}

\subsection{Loads Deflection:}

Deflection has been measured at the slabs' center by $(0.01 \mathrm{~mm})$ dial gage under load increment $2.5 \mathrm{KN}$ and reading for this gages 
were recorded for each load increment. In the case where an RC slab is subjected to gradual increase of the loading, deflection linearly increases with load in elastic way. After cracks begin to develop, slab deflection is increased at faster rates. following the development of the cracks in slab, the curve of the load-deflection is almost non-linear up to flexural reinforcement yielding after which deflection keeps increasing without appreciable load increment.

Figure (1) show that the response of slabs exposed to 150 degrees (GP-0.5-150) (GP-1.0150) approximately similar to the reference slab, at rising the temperature to $(300$ and 450$){ }^{\circ} \mathrm{C}$ the decrease in strength occurs. the result show that increased of deflection at 0.6 Ultimate load of $300{ }^{\circ} \mathrm{C}$ in comparison with $450{ }^{\circ} \mathrm{C}$ because the rate of fire in $300{ }^{\circ} \mathrm{C}$ more than $450{ }^{\circ} \mathrm{C}$ lead to best heat transport.

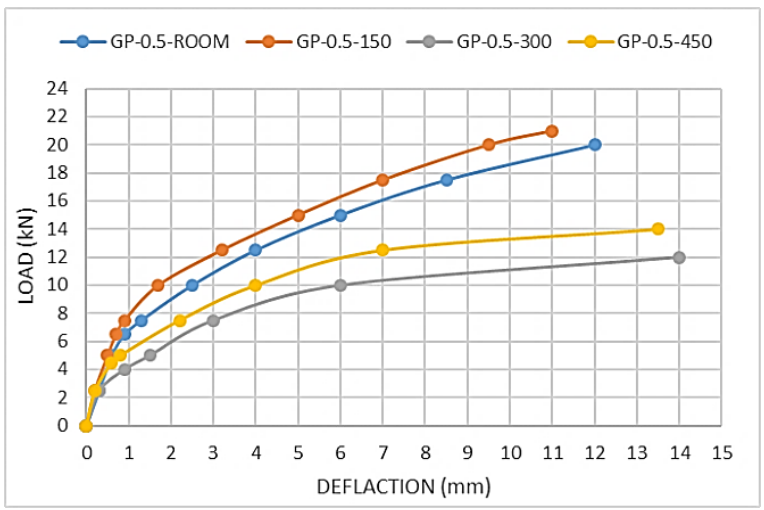

(a)

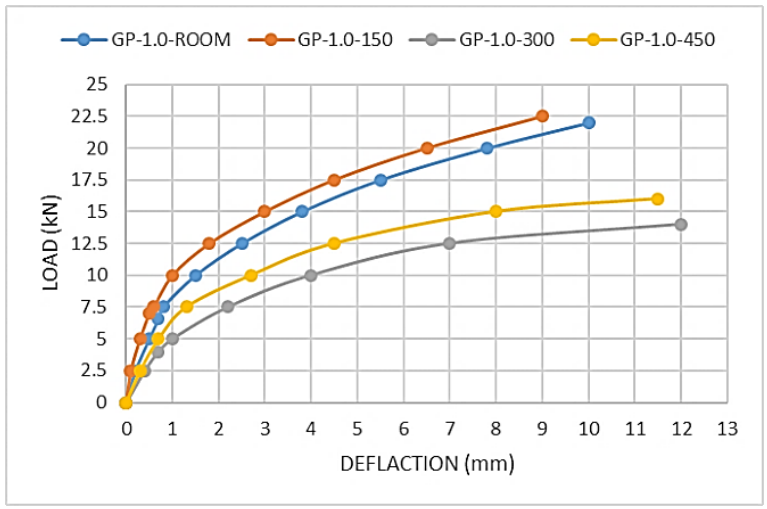

(b)

Figure 1. Show the strength of slabs: (a) GP0.5 (b) GP1.0

\subsection{Size Zone Area of Failure Punching Tested:}

The areas of the punching failure zones are measured by method by Auto Cad, the values of area these methods are illustrated in Table (5). the result show that area of punching load reinforced concrete Geopolymer bubbled slab with $(0.5 \%)$ Glass fiber without exposed to fire flam (GP-0.5-ROOM) was (35\%) from total area of specimen, when slabs exposed to fire flam $(150,300$ and 450$){ }^{\circ} \mathrm{C}$ the punching area increase by $(57 \%, 65 \%$ and $61 \%)$ respectively. identical slabs but with $1.0 \%$ glass fiber the punching area of reference slab was $(30 \%)$ from total area of specimen, when slabs exposed to fire flam $(150,300$ and 450$){ }^{\circ} \mathrm{C}$ the punching area increase by $(50 \%, 58 \%$ and $54 \%)$ respectively. Punching shear area decreasing with increase Glass fiber ratio. Shown in Figure (2) which content 8 picture for punching zone of 8 specimens

Table 5. Area of the Failure Zone of the Tested Slabs

\begin{tabular}{ccc}
\hline $\begin{array}{c}\text { Number } \\
\text { of } \\
\text { specimens }\end{array}$ & Labeling & $\begin{array}{c}\text { Percentage of } \\
\text { punching } \\
\text { From total area (\%) }\end{array}$ \\
\hline $\mathbf{1}$ & GP-0.5- & 35 \\
$\mathbf{2}$ & ROOM & 55 \\
$\mathbf{3}$ & GP-0.5-150 & 57.8 \\
$\mathbf{4}$ & GP-0.5-300 & 56.4 \\
$\mathbf{5}$ & GP-1.0- & 30 \\
& ROOM & \\
$\mathbf{6}$ & GP-1.0-150 & 45 \\
$\mathbf{7}$ & GP-1.0-300 & 47.6 \\
$\mathbf{8}$ & GP-1.0-450 & 46.2 \\
\hline
\end{tabular}

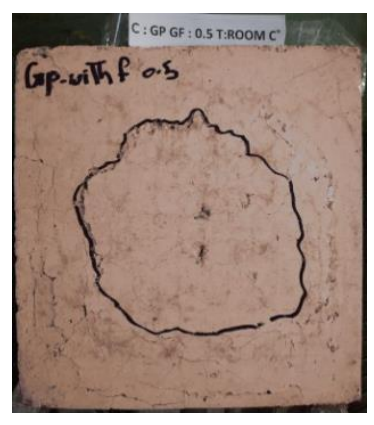

(a) GP-0.5-ROOM

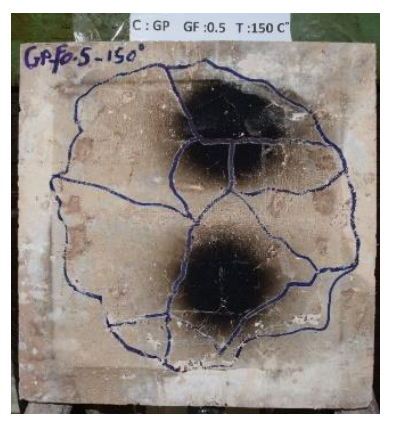

(b) GP-0.5-150 


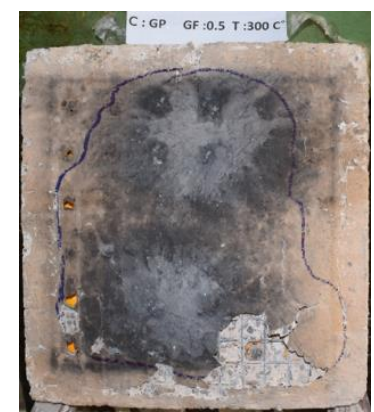

(c) GP-0.5-300

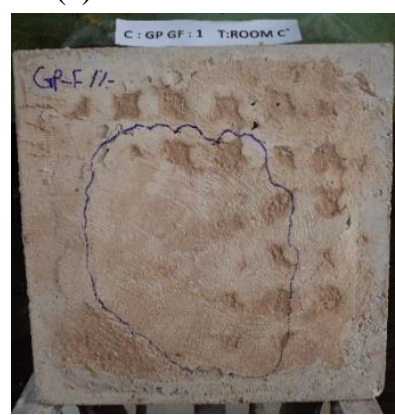

(e) GP-1.0-ROOM

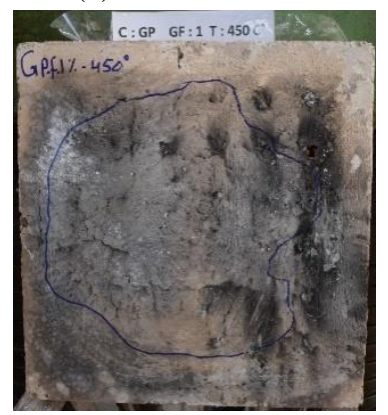

(g) GP-1.0-300

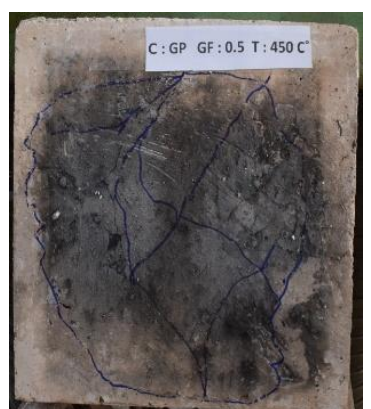

(d) GP-0.5-450

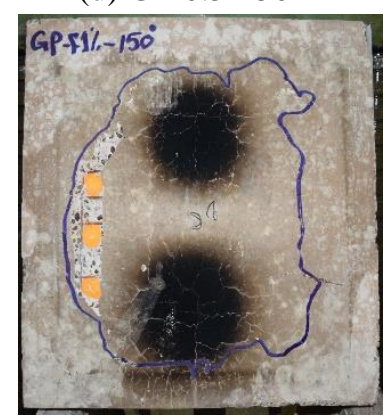

(f) GP-1.0-150

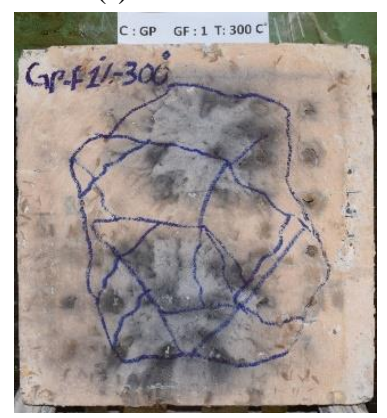

(h) GP-1.0-450
Figure 2. Area of punching zone

\section{Conclusions}

- Increase in Glass fiber lend to increasing ultimate load.

- When Geopolymer concrete bubbled slab exposed to $150{ }^{\circ} \mathrm{C}$ output increase an improvement in ultimate load

- In 300 and $450{ }^{\circ} \mathrm{C}$ ultimate strength decrease due to exposed to elevated temperature.

- Punching shear area decreasing with increase Glass fiber ratio.

- The strength of slabs decrease in $300{ }^{\circ} \mathrm{C}$ is more than $450{ }^{\circ} \mathrm{C}$.

\section{Conflicts of Interest}

The authors confirm that the publication of this article causes no conflict of interest.

\section{References}

1. Haitham. H., Hashim , 2020 "Behavior of Bubbled Reinforced Concrete Slabs Subjected to Fire Flame with Rehabilitation" M. Sc thesis, University of Mustansiriayah, Baghdad, Iraq.

2. Ferone, Claudio, et al. (2013)"Application-oriented chemical optimization of a metakaolin based geopolymer." Materials 6.5: 1920-1939.

3. Faiz Uddin Ahmed Shaikh, (2016) "Mechanical and durability properties of fly ash geopolymer concrete containing recycled coarse aggregates", International Journal of Sustainable Built Environment 5, pp. 277-287.

4. Malhotra V M and Mehta P K., (2002) "High-performance, high-volume fly ash concrete: materials, mixture proportioning, properties, construction practice, and case histories",

5. Davidovits J. (2020)" GEOPOLYMER Chemistry and Application "Fifth edition, Institute geopolymer, France,

6. Salman, W., Dawood, (2012) "Flexural Behavior of Bubbled Reinforced Concrete Slabs", Ph.D. thesis, University of Baghdad, Baghdad, Iraq,.

7. Al-Attar, T. S., Al-Shathr, B. S., and Hasan, Z. A., (2015)"Optimization of Geopolymer Concrete Based on Local Iraqi Metakaolin", The 2nd International Conference of Buildings, Construction and Environmental Engineering BCEE2, pp97100 ,

8. Alsaraj, Wissam Kadhim, and Shaimaa Hasan Fadhil. (2020) "Behavior of reinforced geopolymer concrete flat slab 
exposedtohigh temperature." Periodicals

of Engineering and Natural Sciences 8.3: 1716-1728.

9. ASTM C618-17a., (2017)"Standard Specification for Coal Fly Ash and Raw or Calcined Natural Pozzolan for Use in Concrete", American Society of Testing and Materials, West Conshohocken, PA 19428-2959, USA,

10. ASTM E 291-09, (2009)" Standard test method for Chemical Analysis of Caustic Soda and Caustic Potash (Sodium Hydroxide and Potassium Hydroxide) ", American Society of Testing and Materials, Book of Standards, West Conshohocken, PA 19428-2959, USA.

11. IOS No.45, Iraqi Specification, (1984)"Aggregate from Natural Sources for Concrete and Construction", Central Agency for Standardization and Quality Control, Baghdad,.

12. ASTM A185 / A185M-07, (2013)"Standard Specification for Steel Welded Wire Reinforcement, Plain, for Concrete", (Withdrawn), ASTM International, West Conshohocken, PA, 2007.

13. Alam, Md Abid, Imran Ahmad, and Fazlur Rehman. (2015) "Experimental study on properties of glass fiber reinforced concrete." International Journal of Engineering Trends and Technology 24.6.

14. Sumajouw, M. D. J. and Rangan, B. V. (2006), "LOW-CALCIUM FLY ASHBASED GEOPOLYMER CONCRETE: REINFORCED BEAMS AND COLUMNS", Research Report GC 3, Faculty of Engineering, Curtin University of Technology, Perth, Australia,.

15. Lloyd, N.A. and Rangan, B.V. (2010) "Geopolymer Concrete with Fly Ash", Second International Conference on
Sustainable Construction Materials and Technologies, vol. 3, pp 1493-1504,.

16. Sanni, S.H. and Khadiranaikar, R.B. (2013) "Performance of Alkaline Solutions on Grades of Geopolymer Concrete", International Journal of Research in Engineering and Technology, pp 366-371,. 